\title{
RS analysis of glaciers change in the Heihe River Basin, Northwest China, during the recent decades
}

\author{
HUAI Baojuan ${ }^{1,2}$, LI Zhongqin ${ }^{1,3}$, WANG Shengjie ${ }^{3}$, SUN Meiping ${ }^{3}$, \\ ZHOU Ping ${ }^{1}$, XIAO Yan ${ }^{4}$
}

1. State Key Laboratory of Cryospheric Sciences, Cold and Arid Regions Environmental and Engineering Research Institute/Tianshan Glaciological Station, CAS, Lanzhou 730000, China;

2. University of Chinese Academy of Sciences, Beijing 100049, China;

3. College of Geography and Environmental Sciences, Northwest Normal University, Lanzhou 730070, China;

4. College of Environment and Planning, Liaocheng University, Liaocheng 252059, Shandong, China

\begin{abstract}
The Heihe River Basin is the second largest inland river basin in Northwest China and it is also a hotspot in arid hydrology, water resources and other aspects of researches in cold regions. In addition, the Heihe River Basin has complete landscape, moderate watershed size, and typical social ecological environmental problems. So far, there has been no detailed assessment of glaciers change information of the whole river basin. 1:50,000 topographic map data, Landsat TM/ETM+ remote sensing images and digital elevation model data were used in this research. Through integrated computer automatic interpretation and visual interpretation methods, the object-oriented image feature extraction method was applied to extract glacier outline information. Glaciers change data were derived from analysis, and the glacier variation and its response to climate change in the period 1956/1963-2007/ 2011 were also analyzed. The results show that: (1) In the period 1956/1963-2007/2011, the Heihe River Basin's glaciers had an evident retreat trend, the total area of glaciers decreased from $361.69 \mathrm{~km}^{2}$ to $231.17 \mathrm{~km}^{2}$; shrinking at a rate of $36.08 \%$, with average single glacier area decrease $0.14 \mathrm{~km}^{2}$; the total number of the glaciers decreased from 967 to 800 . (2) Glaciers in this basin are mainly distributed at elevations of $4300-4400 \mathrm{~m}, 4400-4500 \mathrm{~m}$ and 4500-4600 $\mathrm{m}$; and there are significant regional differences in glaciers distribution and glaciers change. (3) Compared with other western mountain glaciers, glaciers retreat in the Heihe River Basin has a higher rate. (4) Analysis of the six meteorological stations' annual average temperature and precipitation data from 1960 to 2010 suggests that the mean annual temperature increased significantly and the annual precipitation also showed an increasing trend. It is concluded that glacier shrinkage is closely related with temperature rising, besides, glacier melting caused by rising temperatures greater than glacier mass supply by increased precipitation to some extent.
\end{abstract}

Keywords: remote sensing detection; glacier; object-oriented extraction method; shrinkage; Landsat TM/ ETM+; Heihe River Basin

Received: 2014-01-03 Accepted: 2014-02-25

Foundation: Funds for Creative Research Groups of China, No.41121001; Project for Incubation of Specialists in Glaciology and Geocryology of National Natural Science Foundation of China, No.J1210003/J0109; National Natural Science Foundation of China, No.41340014; National Basic Research Program of China, No.2013CBA01801

Author: Huai Baojuan (1988-), PhD, specialized in GIS and glaciology. E-mail: huaibaojuan@126.com 


\section{Introduction}

With global warming and rapid shrinkage of glaciers in recent decades (IPCC, 2001), the cryosphere system has gained an unprecedented attention for scientific research (Haeberli et al., 2000; Wang et al., 2014). Cryospheric science is considered to be one of the most active sections of current global change investigation, which is critical for regional and global sustainable development. Glaciers, as an important part of the cryosphere system, are solid reservoir of freshwater resources (Wang et al., 2003). Impacted by global warming, glaciers shrinking is a common trend especially for the mountain glaciers in the High Asia, and China's glaciers were predicted to reduce by $27.20 \%$ in the first half of the 21 st century (Qin et al., 2006). Many studies show that the indicative role of glaciers change in global climate change in this century is more obvious (Shi et al., 2000; Houghton et al., 2001; Yao et al., 2004). River runoff and other water resources are significantly influenced by glaciers change, especially in the arid and semi-arid regions in Northwest China (Shi, 2001). Timely and correct assessment of glaciers change and revealing effects of glaciers change on Northwest China's river runoff are also important. The Heihe River Basin is the second largest inland river basin in Northwest China. Due to its typical natural landscapes and complex man-land relationship, this drainage basin is widely considered to be a representative region of inland river basin (Ning et al., 2008). A comprehensive observation system has been established in this river basin in the recent 30 years, and many researches focused on the regional water resources influenced by the mountain glaciers. In the Heihe River Basin, the annual glaciers melt water from high-altitude glacier in Qilian Mountains is approximately $2.98 \times 10^{8} \mathrm{~m}^{3}$, accounting for $8 \%$ of the total river runoff (Yang, 1991; Feng et al., 2002).

During the past decades, remote sensing (RS) and geographic information systems (GIS) have become widely-used technologies to monitor the dynamic changes of glaciers (Paul et al., 2000; Shangguan et al., 2004). Besides, RS and GIS are also an effective solution to obtaining high mountain glaciers vector data in the study of modern glaciers. Artificial visual interpretation method and computer-assisted classification method are the main steps in extracting glaciers boundary information from the remote sensing images (Serandre et al., 1999; Bolch et al., 2007; Hall et al., 2001). Traditional image analysis methods usually ignore the interrelated information of spatial characteristics within the images; thereby reduce the accuracy of information extraction. In the traditional process, complex shape, texture and other information in images are easy to be considered as noise, which may lead to wrong judgments in image interpretation and misclassification (Huai et al., 2013; Sidjak et al., 1999; Zhang et al., 2011b; Zhang, 2005). Basically, the above-mentioned phenomena in pixel-based image analysis methods is caused by the spectral characteristics for each pixel itself, and internal message within pixel-based image analysis is limited (Wei et al., 2007). Object-oriented extraction method (Nie et al., 2010; Blaschke et al., 2001; Benz et al., 2004; Baatz et al., 2000) provides strong technical support to avoid or reduce the disadvantage of the traditional method only using spectral characteristics. In the new method, remote sensing image can be segmented, and then various features of the divided units were extracted, recognized and identified in the feature space, which means that the classification is completed (Laliberte et al., 2004; Schiewe et al., 2001). This paper applied this method in the glaciers information extraction of the Heihe River Basin. Detailed investigations were done for gla- 
ciers change under climate warming in this river basin.

\section{Study area}

The Heihe River Basin $\left(38^{\circ} \mathrm{N}-42^{\circ} \mathrm{N}, 98^{\circ} \mathrm{E}-101^{\circ} 30^{\prime} \mathrm{E}\right)$ lies on the west of Shiyang River Basin, and on the east to Shule River Basin (Figure 1). The total length of the Heihe River is $821 \mathrm{~km}$ from headstream in Qilian Mountains to Juyan Lake. The upstream watershed of the Heihe River is defined as drainage basin above Yingluoxia (a debouchure out of Qilian Mountains), and the catchment area and average altitude of upstream watershed is 10,009 $\mathrm{km}^{2}$ and $3738 \mathrm{~m}$, respectively. The total surface runoff of the upstream watershed is $25.11 \times 10^{8} \mathrm{~m}^{3}$ (Yellow River Conservancy Committee, 2010; http://www.yellowriver.gov.cn). The Heihe River Basin includes three main landform types, i.e., Qilian Mountains (upstream), Hexi Corridor plains (midstream) and Alxa Highland (downstream). Modern glaciers are widely distributed at the high-altitude mountains of the upstream watershed. Based on the aerial photographs taken in 1956 and 1963 (painted in 1964 and 1972), the first Glacier Inventory of China (GIC) of Qilian Mountains was completed by the former Lanzhou Institute of Glaciology and Cryopedology (LIGG), Chinese Academy of Sciences (CAS) in 1981 (Wang et al., 1981). According to the first GIC, there are 1078 glaciers in the Heihe River Basin with a total area and an ice volume being $420.55 \mathrm{~km}^{2}$ and $13.67 \mathrm{~km}^{3}$, respectively. The average area of single glacier is $0.39 \mathrm{~km}^{2}$, and the average snow line is 4410-4850 m.

It should be noted that the boundary of the Heihe River Basin is not completely consistent in different researches. According to the map of the Heihe River Basin drawn in 1985-1986, the whole basin is composed of three hydrologic balance units, namely, Heihe River, Beida River and Maying-Fengle Mountain Front, respectively. In general, this boundary includes Heihe River and Beida River. However, according to the first GIC, glaciers in the Heihe River and Beida River are listed separately. In this study, the generalized glaciers located in the Heihe River and Beida River are all included for analyzing distribution and variation of glaciers.

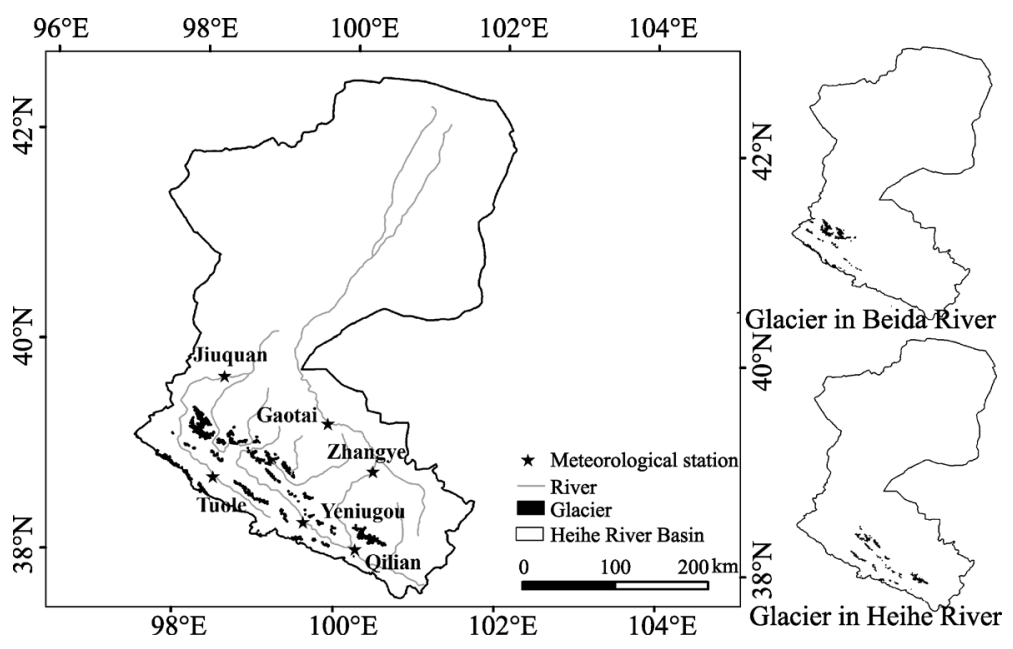

Figure 1 Location of the Heihe River Basin 


\section{Data processing and method}

\subsection{Data sources}

The glacier vector boundary in the 1960s was derived from topographic maps using aerial photographs. The glaciers of the Heihe River Basin involve 16 topographic maps at a scale of 1:50,000 and 14 topographic maps of 1:100,000. The original aerial photographs were taken in 1956 and 1963 and then painted in 1964 and 1972, respectively. In 1973, the first edition of these maps was published. The coordinates system is Beijing 1954, and the elevation system is Yellow Sea system 1956. In this study, the topographic maps were scanned with a resolution of $300 \mathrm{dpi}$.

A total of 4 scenes of Landsat TM/ETM+ digital images were also used in this work, and the data are acquired from U.S. Geological Survey (USGS, http://www.usgs.gov) data sharing platform (Table 1). Digital elevation model (DEM) is derived from Shuttle Radar Topography Mission (SRTM), which is jointly measured by National Aeronautics and Space Administration of USA (NASA) and the Department of Defense National Mapping Agency of USA (NIMA). The revision V4.1 with a horizontal resolution of $90 \mathrm{~m}$ was used in this study. This version data was obtained with new interpolation algorithm by International Center for Tropical Agriculture (CIAT), which was considered to be better than the previous versions by filling the void SRTM90 data. The nominal absolute elevation data accuracy is $\pm 16 \mathrm{~m}$, and the absolute accuracy of plane surface is $\pm 20 \mathrm{~m}$.

Table 1 Remote sensing images of the Heihe River Basin used in this study

\begin{tabular}{ccccc}
\hline ID & Receive date & Sensor & Resolution (m) & Path \\
\hline L5135033_03320070601 & $2007-06-01$ & TM & 28.5 & $135 / 033$ \\
L5133034_03420090928 & $2009-09-28$ & TM & 28.5 & $133 / 034$ \\
L71133033_03320110809 & $2011-08-09$ & ETM+ & $28.5 / 15$ & $133 / 033$ \\
L5134033_03320100805 & $2010-08-05$ & TM & 28.5 & $134 / 033$ \\
\hline
\end{tabular}

The first GIC data was also applied in interpreting the vector data of glaciers in the 1960s as a consult. The data was provided by the Cold and Arid Regions Environmental and Engineering Research Institute (CAREERI), Chinese Academy of Sciences. Besides, boundary vector data of the Heihe River Basin was provided by the Cold and Arid Regions Science Data Center at Lanzhou (http://westdc.westgis.ac.cn). Meteorological data from six stations (Tuole, Yeniugou, Qilian, Zhangye, Gaotai, Jiuquan) were supplied by the Chinese Meteorological Science Data Sharing Service Network (http: //cdc.cma.gov.cn).

\subsection{Data preprocessing}

Preprocessing of topographic map data included scanning, registration and mosaicing. The topographic maps were scanned into digitized products, and then were corrected using grid. Root mean square error (RMSE) of geometric correction is less than one pixel. Preprocessing of image data included accurate geometric correction and image enhancement. All the data were presented in a Universal Transverse Mercator (UTM) coordinate system and World Geodetic System 1984 (WGS84) referenced to the topographic maps. 


\subsection{Method}

Glacier boundary vector data in the 1960s were digitized from topographic maps in the Heihe River Basin using ArcGIS10. Recent glaciers boundary vector data in 2007/2011 were extracted through object-oriented classification method, besides, computer automatic interpretation and visual interpretation methods were also used as a consult. Above all, we referred to the expert guidance to further revise glaciers boundaries in 2007/2011. To sum up, glaciers area, average length and other attributes such as latitude and longitude information of the two periods were obtained by ArcGIS10. Moreover, through the use of SRTM-DEM V4, glaciers terminus elevation, glaciers average elevation, slope, orientations and other attribute information were also calculated. Eventually, overlay analysis of topographic maps glaciers vector data in the 1960s and recent glaciers vector data in 2007/2011 were carried out by ArcGIS10 spatial module to obtain glaciers change information and also to obtain glaciers area variation rules (Figure $2 \mathrm{a}$ ).

By collecting objects near the pixel, these objects were used for identifying interest spectral features by object-oriented classification. This classification is divided into two processes (Wei et al., 2007): image objects construction and image objects classification (Figure 2b). Firstly, specifically segmentation method was used for remote sensing image segmentation. Then, the various features of dividing cells were extracted. Finally, objects in the feature space were recognized and identified, thus the classification was completed. Compared with pixel-based image classification methods, the object-oriented classification can effectively restrain the 'salt and pepper' effect and improve classification accuracy by segmentation and establishing homogeneous regions (Nie et al., 2010; Blaschke et al., 2001; Benz et al., 2004).

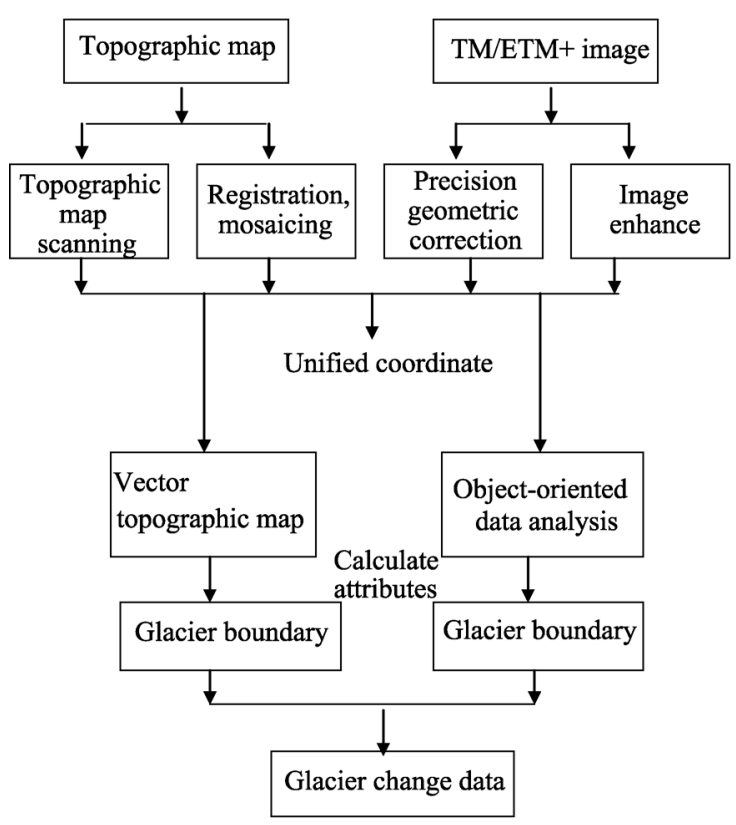

(a) Glacier change flowchart

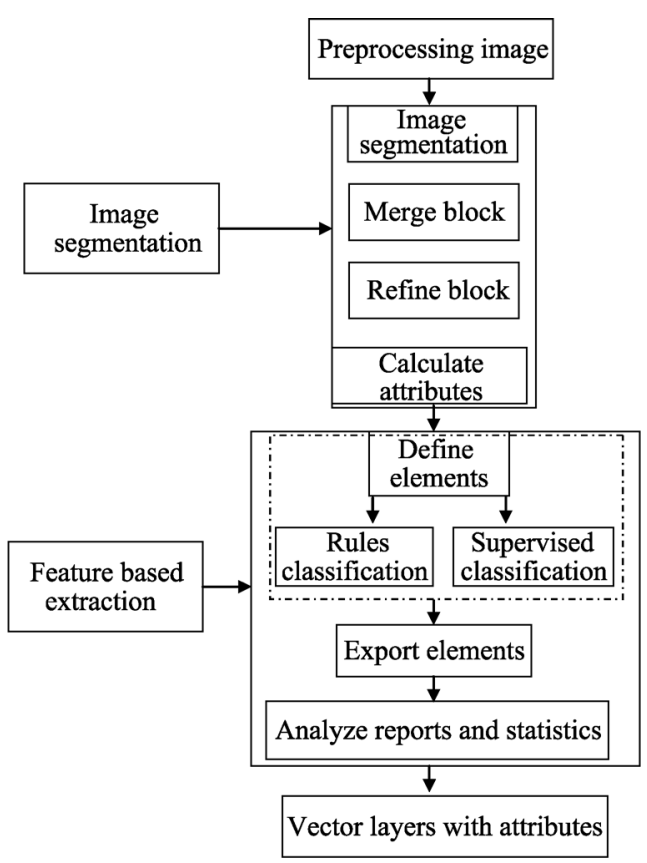

(b) Object-oriented method flowchart

Figure 2 Technical flowchart of derived glaciers 


\subsubsection{Image segmentation}

As a first step, spectral features and shape features of Landsat image were integrated to compute comprehensive values of spectral heterogeneity and shape heterogeneity of each band with multi-scale segmentation algorithm. As a second step, all the bands' integrated weight values were calculated according to the share weight of each band. Then, if the divided objects' integrated weight values were less than a specified threshold value; repeat the iteration calculation until all the segmented objects' integrated weight value greater than the specified threshold value. Finally, the image multi-scale segmentation operation was completed (Guo et al., 2008). In order to achieve the multi-scale segmentation process and the original image objects extraction, we use ENVI EX performs for the calculation. In the process of image segmentation, continuous tests for different scale parameters were executed based on artificial visual effects for the accuracy of information extraction. Eventually, the appropriate scale parameters were chosen. Through trial and error again and again, finally we determine the segmentation scale parameter and the combined scale parameter of pure ice were $70 \%$ and $80 \%$, respectively (Figure 3 ).

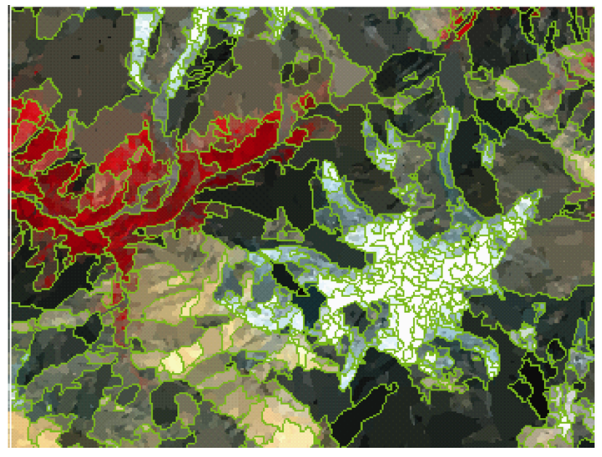

(a) Segmentation scale $50 \%$, combination scale $70 \%$

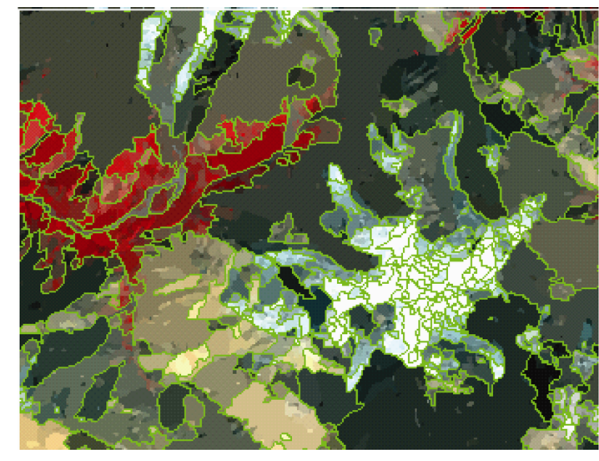

(b) Segmentation scale $70 \%$, combination scale $80 \%$

Figure 3 Different scales of segmentation and combination image in the Heihe River Basin

\subsubsection{Build knowledge rules}

In this section, the most important thing is to find the threshold value of each related band manually. Certainly, spectral characteristics of each band, correlative index of spatial structure and histogram of images were referred to for the process of finding the threshold value. Indexes with target objects and other objects differing obviously are selected to set thresholds of target objects and other objects respectively, then the threshold of the index test was repeatedly set according to visual preview. Finally, all the thresholds of correlative index were integrated to determine the boundary of the target objects. The various types of knowledge rules used were as follows (Blaschke, 2010; Lahousse et al., 2011): (1) The Normalized Difference Snow/Ice Index (NDSII) was used to distinguish glaciers and other landform types. The formula is NDSI $=(\mathrm{CH}(2)-\mathrm{CH}(5)) /(\mathrm{CH}(2)+\mathrm{CH}(5))$. Due to ice in the visible band has a high spectral reflectance value and has a lower spectral reflectance in short wave infrared spectral band, the combination of the two bands can effectively extract ice and snow (Xiao et al., 2001; Willmes et al., 2009). (2) Band ratio method is not obvious when distinguishing and enhancing spectral brightness value, but effect is obvious when band ratio value of different types of landscape with larger differences. Selecting TM3 and 
TM5 band ratio as threshold value of 2 to extract the glacier boundary. (3) In addition, glaciers elevation, area size and other characteristics were used to take a certain threshold. The defined threshold is extremely important for extracting glaciers. Definitive knowledge of glacier boundary extraction rules are as follows: TM3/TM5 $>2.0, \& 0.46<\mathrm{NDSI}<0.58, \&$ $\mathrm{DEM}>4200 \mathrm{~m}, \&(\mathrm{TM} 4-\mathrm{TM} 1) /(\mathrm{TM} 4+\mathrm{TM} 1)>-0.44, \& 0.01 \mathrm{~km}^{2}<$ area $<6 \mathrm{~km}^{2}$.

\subsubsection{Glacier ridgeline extraction}

For automatic extraction of glaciers from Landsat images, the extraction of ridgeline is essentially the extraction of watershed lines. This ridgeline automatic extraction method is based on regular grid of SRTM-DEM V4 data, using the plane curvature and slope-shaped combination algorithms to achieve (Tang et al., 2006). The purpose of extracting the plane curvature and positive terrain is that the maximum plane curvature of the positive terrain is just the ridgeline. However, problems arose as the plane curvature is relatively cumbersome to extract. To achieve this, aspect variability which to some extent can be a good characterization of plane curvature is obtained to replace the plane curvature in ArcGIS10. Object-oriented automated extraction process is shown in Figure 4.
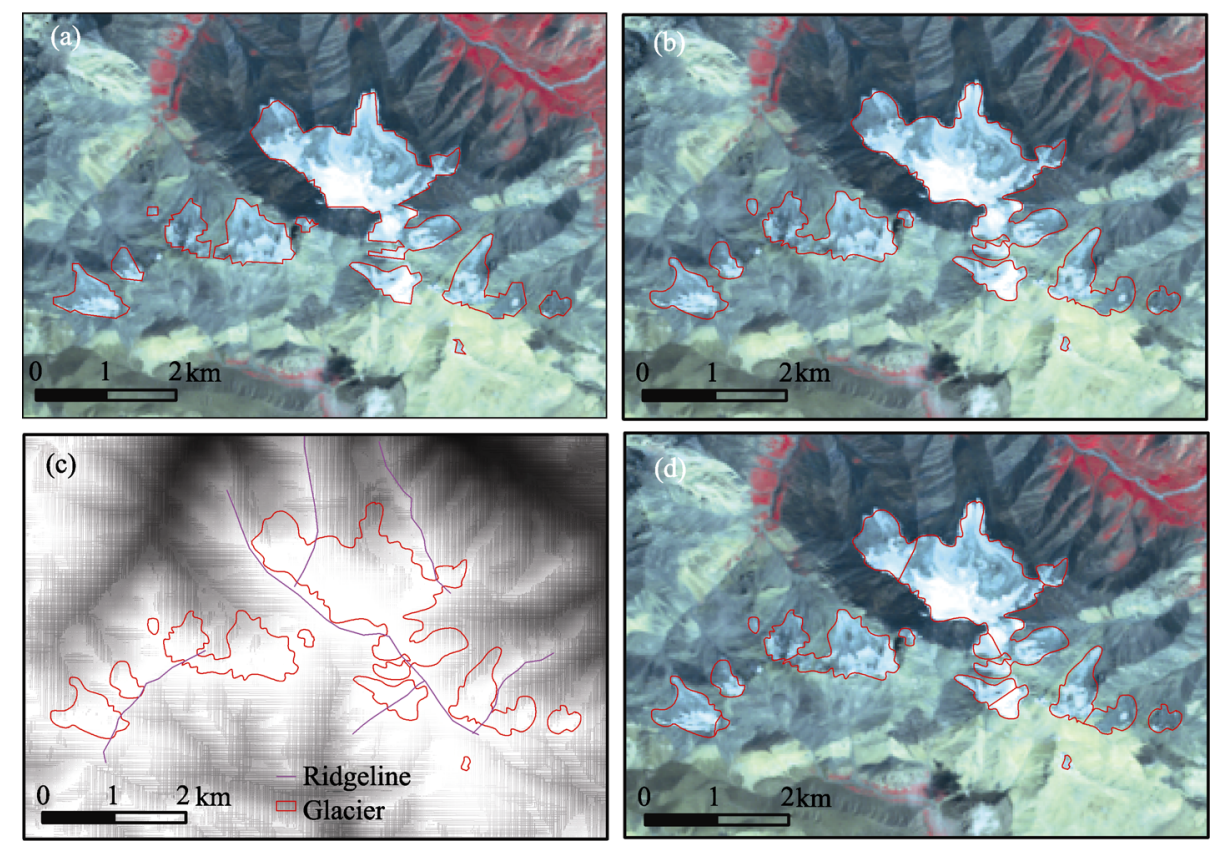

Figure 4 Object-oriented extraction process

(a) Glaciers boundary by object-oriented method; (b) Glaciers boundary by manual correction and smoothing; (c) Ridgelines of glacier region; (d) Ridgelines cutting glaciers

\subsubsection{Accuracy assessment}

Errors in the linear uncertainty from remote sensing image interpretation were affected by the image resolution and co-registration error. This study evaluated object-oriented method extraction errors by two ways: (1) Image resolution and co-registration errors. Remote sensing images spatial resolution (28.5 $\mathrm{m}$ for TM or ETM+ data) and RMSE of co-registration affect the accuracy of measurement. The uncertainty of each position can be calculated by the following formulas (Hall et al., 2003; Silverio et al., 2005; Ye et al., 2006): 


$$
\begin{gathered}
U_{T}=\sqrt{\sum \lambda^{2}}+\sqrt{\sum \varepsilon^{2}} \\
U_{A}=2 U_{T} \sqrt{\sum \lambda^{2}}+\sqrt{\sum \varepsilon^{2}}
\end{gathered}
$$

where $U_{T}$ is the uncertainty of glacier length; $\lambda$ is the image resolution; $\varepsilon$ is the co-registration errors; $U_{A}$ is the uncertainty of glacier area. Result of single glacier area uncertainty is $\pm 0.002 \mathrm{~km}^{2}$. (2) Glaciers extraction errors affected by debris. The greatest difficulty in mapping glaciers using remote sensing automatic classification is the presence of debris cover on glaciers. Currently, computer automatic classification method is not able to fully resolve same object with different spectral and different objects with same spectral phenomena. For debris-covered glaciers, as computer automatic extraction method is still in constant exploration, object-oriented extraction method did not consider this part of glaciers. This research used artificially visual interpretation for its accurate correction.

\section{Results and discussion}

\subsection{Spatial characteristics of recent glaciers change in the Heihe River Basin}

Due to the quality problem of Landsat images, part of the glaciers covered with snow or clouds, so just 967 glaciers(464 glaciers in Heihe River and 503 glaciers in Beida River) were focused on in this basin (total number of glaciers is 1078 in the Heihe River Basin) in

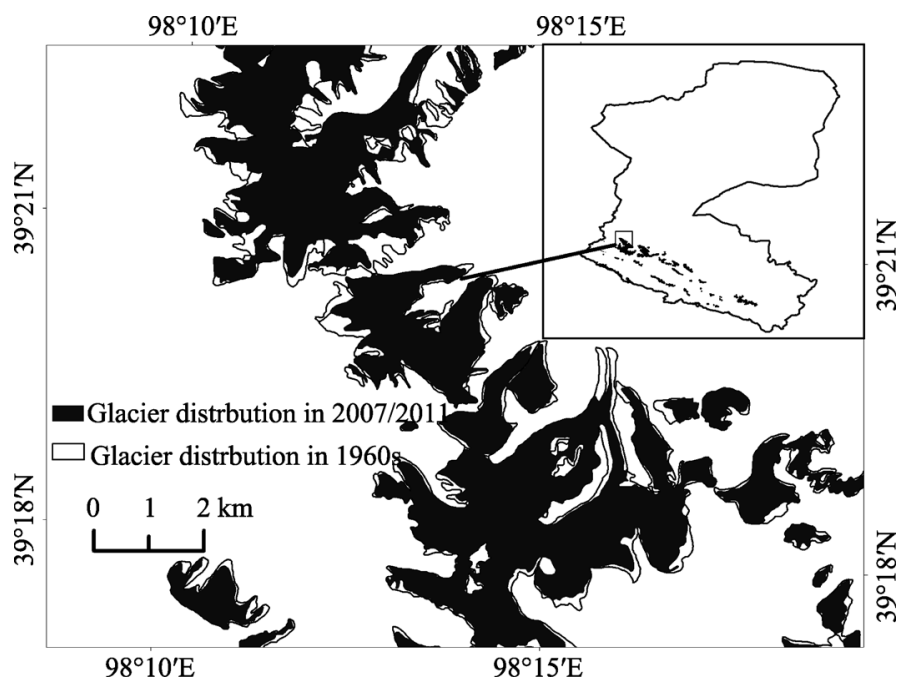

Figure 5 Glacier shrinkage in the Heihe River Basin this study. The results show that: 967 glaciers were decreased to 800 in the Heihe River Basin from the 1960s to 2007/2011, and the rate of recession in the number of glaciers was $17.27 \%$, showing obvious shrinkage trends (Figure 5). The glaciers area was decreased from 361.69 $\mathrm{km}^{2}$ to $231.17 \mathrm{~km}^{2}$ which means a total area of 130.51 $\mathrm{km}^{2}$ was lost, shrinking rate was $36.08 \%$. Apparently, the average reduction of each glacier was $0.14 \mathrm{~km}^{2}$ from the 1960 s to $2007 / 2011$. The magnitude of glaciers change, regional difference, and climate background in the past 50 years and so on will be presented as follows.

\subsubsection{Glacier area and number change}

Glaciers were divided into nine grades because the sizes of glaciers area in the Heihe River Basin are generally small (most glaciers is less than $1 \mathrm{~km}^{2}$ ): (1) $<0.1 \mathrm{~km}^{2}$; (2) $0.1-0.2 \mathrm{~km}^{2}$; (3) $0.2-0.3 \mathrm{~km}^{2}$; (4) $0.3-0.4 \mathrm{~km}^{2}$; (5) $0.4-0.5 \mathrm{~km}^{2}$; (6) $0.5-1 \mathrm{~km}^{2}$; (7) $1-2 \mathrm{~km}^{2}$; (8) $2-5 \mathrm{~km}^{2}$; (9) $>5$ 
$\mathrm{km}^{2}$. As shown in Figure 6: glaciers which have area size $<0.1$ $\mathrm{km}^{2}$ have its area and number increased by $10.01 \%$ and $42.44 \%$ respectively; and area size $0.1-0.2$ $\mathrm{km}^{2}$ have its area and number decreased by $32.09 \%, \quad 31.47 \%$; $0.2-0.3 \mathrm{~km}^{2}$ decreased by $37.32 \%$, $46.09 \%$ respectively; and $0.3-0.4$ $\mathrm{km}^{2}$ were $30.16 \%, 28.89 \%$ respectively; $0.4-0.5 \mathrm{~km}^{2}$ were $48.48 \%$, $48.68 \%$ respectively; $0.5-1 \mathrm{~km}^{2}$ were $45.63 \%$, 46.09\% respectively;

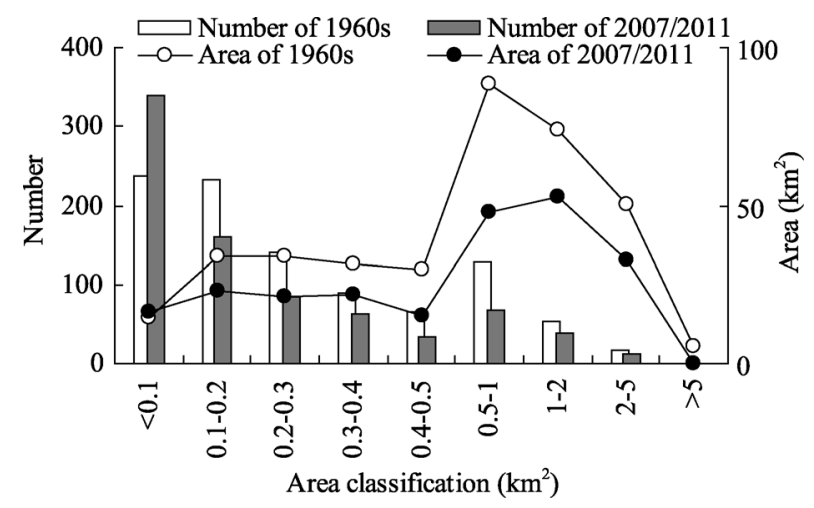

Figure 6 Change of glacier area and number in the Heihe River Basin

$1-2 \mathrm{~km}^{2}$ were $28.61 \%$ and $28.30 \%$;

$2-5 \mathrm{~km}^{2}$ were $34.94 \%$ and $38.89 \%$; glaciers $>5 \mathrm{~km}^{2}$ were $100 \%$ and $100 \%$. There is only one glacier with an area greater than $5 \mathrm{~km}^{2}$, the number of which is $5 \mathrm{Y} 433 \mathrm{~B} 0039$ and glacier area is $5.61 \mathrm{~km}^{2}$. This glacier was split into two glaciers (area being $4.62 \mathrm{~km}^{2}$ and $0.13 \mathrm{~km}^{2}$ respectively) in 2011. Apparently, high recession of glaciers in the Heihe River Basin directly resulted in an increase of glaciers with area $<0.1 \mathrm{~km}^{2}$ and decrease in number.

\subsubsection{Characteristics of glacier variation in different altitude ranges}

Using SRTM-DEM V4 data, vertical variations were calculated for each $100 \mathrm{~m}$ elevation gradients according to the elevation of glacier terminal. Statistical analysis was carried on for the two phases of the glacier data (Figure 7): glaciers termini in the Heihe River Basin were mainly distributed at 4300-4400 m, 4400-4500 m and 4500-4600 m, accounting for $20 \%, 24.5 \%$ and $19.38 \%$ of the total number respectively, or $63.88 \%$ of the grand total.

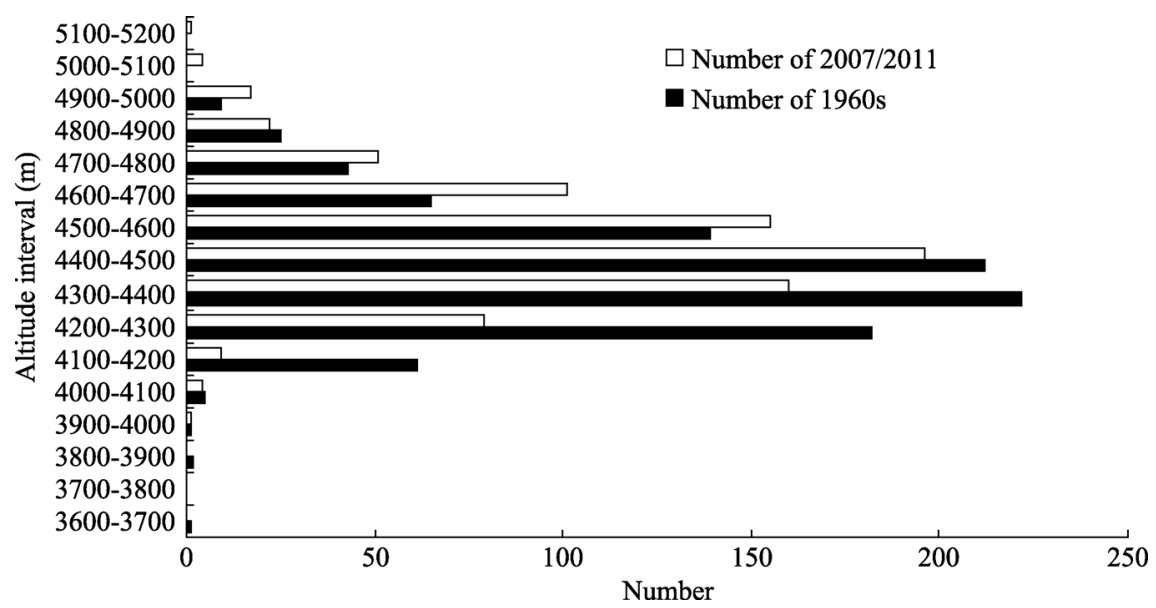

Figure 7 Change of terminal elevation of the Heihe River Basin

From the changing trend of the glaciers, the number decreased in four elevation ranges: $4100-4200 \mathrm{~m}, 4200-4300 \mathrm{~m}, 4300-4400 \mathrm{~m}$ and $4400-4500 \mathrm{~m}$. The reduction rates of the four ranges were: $85.25 \%, 56.59 \%, 27.93 \%$ and $7.55 \%$ respectively. The most obviously reduction ranges are in the altitude range of 4100-4200 m and 4200-4300 m. Apparently, 
the high shrinking rate of glaciers at the altitude range of 4100-4500 m directly led to an increasing trend at altitude range of 4500-4800 m. Rates of glaciers number increasing at range of 4500-4600 m, 4600-4700 $\mathrm{m}$ and 4700-4800 $\mathrm{m}$ were $11.51 \%, 55.38 \%$ and $18.60 \%$ respectively. These facts show clearly that, as global temperatures rising generally, the snowline is going up with the terminal elevation of glaciers ascending in the Heihe River Basin.

\subsubsection{Glacier distribution and regional differences}

In this section, the differences in glaciers change between Heihe River and Beida River are compared, and each branch of the two subbasins are analyzed. Statistical information of Heihe River and Beida River are shown in Table 2. It is clear that distribution and changes of glaciers have significant regional differences. Glacier shrinking rate in Heihe River was $46.07 \%$, which is much higher than that of Beida River $(29.55 \%)$. These differences were mainly related with glacier area. Average area of 464 glaciers in Heihe River was $0.31 \mathrm{~km}^{2}$, and average area of 503 glaciers of Beida River was $0.43 \mathrm{~km}^{2}$. Generally, small glaciers were more sensitive to climate change. In previous research (Jia et al., 2008), summer warming trend in the Heihe River Basin is $0.27^{\circ} \mathrm{C}$ per decade during the $1960 \mathrm{~s}-2005$, greater than that in Beida River $\left(0.21^{\circ} \mathrm{C} / 10 \mathrm{a}\right)$. In this study, the rate of glacier retreat in Heihe River was about 16\% higher than that of Beida River.

Statistical results of glaciers distribution in Heihe River (Table 3) revealed that glaciers number in Dahe River (a tributary of Heihe River) remain unchanged, but with the rate of area change being $-43.8 \%$. Although the number of glaciers did not change in this tributary, area decreased significantly. Eight small glaciers disappeared completely, and 3 small

Table 2 Glaciers change of Heihe River and Beida River

\begin{tabular}{|c|c|c|c|c|c|c|}
\hline \multirow{2}{*}{ Subbasin } & \multicolumn{3}{|c|}{ Number of glaciers } & \multicolumn{3}{|c|}{ Area of glaciers $\left(\mathrm{km}^{2}\right)$} \\
\hline & $1960 \mathrm{~s}$ & $2007 / 2011$ & Change rate $(\%)$ & $1960 \mathrm{~s}$ & $2007 / 2011$ & Change rate $(\%)$ \\
\hline Heihe River (5Y42) & 464 & 365 & -21.34 & 143.18 & 77.22 & -46.07 \\
\hline Beida River (5Y43) & 503 & 435 & -13.52 & 218.51 & 153.95 & -29.55 \\
\hline Total & 967 & 800 & -17.27 & 361.69 & 231.17 & -36.08 \\
\hline
\end{tabular}

Table 3 Glaciers change of Heihe River

\begin{tabular}{|c|c|c|c|c|c|c|}
\hline \multirow{2}{*}{ Branch } & \multicolumn{3}{|c|}{ Number of glaciers } & \multicolumn{3}{|c|}{ Area of glaciers $\left(\mathrm{km}^{2}\right)$} \\
\hline & $1960 s$ & $2007 / 2011$ & Change rate $(\%)$ & $1960 \mathrm{~s}$ & $2007 / 2011$ & Change rate $(\%)$ \\
\hline Dahe River & 61 & 61 & 0 & 21.04 & 11.82 & -43.80 \\
\hline Jiadao-Panjia River & 18 & 20 & 11.11 & 5.76 & 3.29 & -42.97 \\
\hline Babao River & 42 & 35 & -16.67 & 12.58 & 5.69 & -54.77 \\
\hline Kekeli River & 53 & 41 & -22.64 & 19.46 & 10.01 & -48.54 \\
\hline Upstream of Heihe River & 79 & 56 & -29.11 & 20.99 & 11.34 & -45.95 \\
\hline Changqian River & 41 & 22 & -46.34 & 6.83 & 1.43 & -79.14 \\
\hline Liyuan River & 66 & 51 & -22.73 & 17.56 & 8.88 & -49.40 \\
\hline Bailang River & 31 & 29 & -6.45 & 16.24 & 12.28 & -24.36 \\
\hline Maying River & 73 & 50 & -31.51 & 22.72 & 12.48 & -45.07 \\
\hline Total & 464 & 365 & -21.34 & 143.18 & 77.22 & -46.07 \\
\hline
\end{tabular}


glaciers developed newly. In addition, 4 large glaciers split into 9 glaciers. Glaciers number in Jiadao-Panjia River increased from 18 to 20, 2 glaciers disappeared in this tributary. Three large glaciers split into 7 small glaciers, and no new glaciers developed. The rate of glaciers number recession in Changqian River was the largest, accounting for $46.34 \%$, while Bailang River was smaller, $6.45 \%$, and rate of glaciers number recession was equal in other branches. The largest area shrinking rate was also found in Changqian River, 79.14\%; other tributary glaciers area recession were equal, being about $40 \%-50 \%$. The statistical results in Beida River showed that (Table 4): compared with Fengle River and Hongshuiba River, rate of glaciers number and area recession in Zhulongguan River and Right bank of Beida River were higher. Glaciers number of Gaoya Well increased by two, but the rate of area shrinkage was $24.78 \%$, similar to Dahe River.

\section{Table 4 Glaciers change of Beida River}

\begin{tabular}{|c|c|c|c|c|c|c|}
\hline \multirow{2}{*}{ Branch } & \multicolumn{3}{|c|}{ Number of glaciers } & \multicolumn{3}{|c|}{ Area of glaciers $\left(\mathrm{km}^{2}\right)$} \\
\hline & $1960 \mathrm{~s}$ & $2007 / 2011$ & Change rate $(\%)$ & $1960 \mathrm{~s}$ & $2007 / 2011$ & Change rate $(\%)$ \\
\hline Fengle River & 60 & 53 & -11.67 & 24.94 & 18.06 & -27.58 \\
\hline Hongshuiba River & 150 & 131 & -12.67 & 79.98 & 56.61 & -29.23 \\
\hline Zhulongguan River & 149 & 110 & -26.17 & 62.86 & 41.83 & -33.46 \\
\hline Right bank of Beida River & 23 & 18 & -21.74 & 4.05 & 2.34 & -42.12 \\
\hline Gaoya Well & 121 & 123 & 1.65 & 46.67 & 35.11 & -24.78 \\
\hline Total & 503 & 435 & -13.52 & 218.51 & 153.95 & -29.55 \\
\hline
\end{tabular}

\subsection{Discussion}

\subsubsection{Comparative recession analysis of typical mountain glaciers}

Under the background of global warming, global mountain glaciers showed widespread shrinking trend (Haeberli, 2000; Shi et al., 2002). While the high resolution satellite image data have been widely used in glacier dynamic monitoring in recent years, studies of glaciers change in large area are possible to achieve. In order to further analyze characteristics of glaciers change in the Heihe River Basin, we choose typical mountains and basins glaciers in western China to compare with this study (Table 5). Considering the research period, combined with researches that scholars have made including Lenglong Range of Qilian Mountains (Zhang et al., 2010), Shulenan Range of Qilian Mountains (Zhang et al., 2011a), Yeniugou Watershed in Qilian Mountains (Yang et al., 2007), the statistical analysis of glaciers change research in west regions of China was made. It is found that compared with other glaciers in western mountains, the rate of glaciers retreat was significantly higher in this study. Zhang et al. (2010) found that glaciers decreased by $0.67 \% / \mathrm{a}$ in Lenglong Range during 1972-2007; Yang (2007) discovered that glaciers in Yeniugou Watershed showed a recession rate of $0.54 \%$ /a from 1956 to 2003. Our research revealed that 967 glaciers in the Heihe River Basin decreased by $0.60 \%$ /a from the 1960 s to $2007 / 2011$. Compared with the glaciers recession rate of other mountains of western China, such as Tianshan Mountains (Wang et al., 2011b) (0.22\%/a), A'nyêmaqên Mountains (Liu et al., 2002a) (0.49\%/a), Geladaindong Mountains (Lu et al., 2002) (0.05\%/a), Naimona Nyi Mountains (Ye et al., 2007) $(0.26 \% / a)$, the Heihe River Basin showed a higher retreat trend. 
Table 5 Shrinkage of the typical mountain glaciers in China

\begin{tabular}{|c|c|c|c|c|c|c|c|}
\hline Study areas & $\begin{array}{l}\text { Area } \\
\text { change } \\
\left(\mathrm{km}^{2}\right)\end{array}$ & $\begin{array}{l}\text { Change } \\
\text { rate } \%\end{array}$ & $\begin{array}{l}\text { Recession } \\
\text { rate }(\% / a)\end{array}$ & Data source & Method & Period & Author \\
\hline $\begin{array}{l}\text { Lenglong } \\
\text { Range of Qilian } \\
\text { Mountains }\end{array}$ & -24.29 & -23.57 & -0.67 & $\begin{array}{l}\text { Topographic } \\
\text { map, ETM }\end{array}$ & $\begin{array}{c}\text { Visual } \\
\text { interpretation }\end{array}$ & 1972-2007 & $\begin{array}{l}\text { Zhang et al., } \\
2010\end{array}$ \\
\hline $\begin{array}{l}\text { Shulennan } \\
\text { Range of Qilian } \\
\text { Mountains }\end{array}$ & -55.00 & -12.80 & -0.36 & $\begin{array}{l}\text { Topographic } \\
\text { map, ETM }\end{array}$ & $\begin{array}{c}\text { Visual } \\
\text { interpretation }\end{array}$ & 1970-2006 & $\begin{array}{c}\text { Zhang et al., } \\
2011 \mathrm{a}\end{array}$ \\
\hline $\begin{array}{l}\text { Yeniugou River } \\
\text { Basin of Qilian } \\
\text { Mountains }\end{array}$ & -16.22 & -25.71 & -0.54 & $\begin{array}{l}\text { Topographic } \\
\text { map, ASTER }\end{array}$ & $\begin{array}{c}\text { Visual } \\
\text { interpretation }\end{array}$ & 1956-2003 & $\begin{array}{c}\text { Yang et al., } \\
2007\end{array}$ \\
\hline $\begin{array}{l}\text { Western Qilian } \\
\text { Mountains }\end{array}$ & -124.2 & -10.3 & -0.29 & $\begin{array}{l}\text { Aerial photo, } \\
\text { ETM }\end{array}$ & $\begin{array}{c}\text { Visual } \\
\text { interpretation }\end{array}$ & 1956-1990 & $\begin{array}{l}\text { Liu et al., } \\
2002 \mathrm{~b}\end{array}$ \\
\hline $\begin{array}{l}\text { Heihe River } \\
\text { Basin }\end{array}$ & -32.41 & -29.6 & - & $\begin{array}{l}\text { Topographic } \\
\text { map, ASTER }\end{array}$ & $\begin{array}{c}\text { Visual } \\
\text { interpretation }\end{array}$ & $\begin{array}{c}1950 \mathrm{~s} / 1970 \\
\mathrm{~s}-2003\end{array}$ & $\begin{array}{l}\text { Wang et al., } \\
\text { 2011a }\end{array}$ \\
\hline $\begin{array}{l}\text { Chinese Tian- } \\
\text { shan Mountains }\end{array}$ & - & -11.5 & -0.22 & - & - & 1960-2010 & $\begin{array}{l}\text { Wang et al., } \\
\text { 2011b }\end{array}$ \\
\hline $\begin{array}{l}\text { Urumqi River } \\
\text { Basin }\end{array}$ & -6.65 & -13.8 & -0.45 & $\begin{array}{c}\text { Aerial photo, } \\
\text { Topographic map, }\end{array}$ & $\begin{array}{l}\text { Aerophoto } \\
\text { grametry }\end{array}$ & 1962-1992 & $\begin{array}{c}\text { Chen et al., } \\
1996\end{array}$ \\
\hline $\begin{array}{l}\text { Kaidu River } \\
\text { Basin }\end{array}$ & -38.5 & -11.6 & -0.31 & $\begin{array}{c}\text { Topographic map, } \\
\text { TM, ETM+ }\end{array}$ & $\begin{array}{c}\text { Visual } \\
\text { interpretation }\end{array}$ & $1963-2000$ & Liu et al., 2006 \\
\hline $\begin{array}{l}\text { Gez River } \\
\text { Basin }\end{array}$ & -188.1 & -10 & -0.26 & $\begin{array}{c}\text { Topographic map, } \\
\text { TM, ETM+ }\end{array}$ & $\begin{array}{c}\text { Visual } \\
\text { interpretation }\end{array}$ & 1960-1999 & Liu et al., 2006 \\
\hline $\begin{array}{l}\text { A'nyêmaqên } \\
\text { Mountains }\end{array}$ & -21.7 & -17.0 & -0.49 & $\mathrm{TM}$ & $\begin{array}{c}\text { Visual } \\
\text { interpretation }\end{array}$ & 1966-2000 & Liu et al., 2002 \\
\hline $\begin{array}{l}\text { Geladaindong } \\
\text { Mountains }\end{array}$ & -14.91 & -1.7 & -0.05 & Aerial photo, TM & $\begin{array}{c}\text { Visual } \\
\text { interpretation }\end{array}$ & 1969-2000 & Lu et al., 2002 \\
\hline $\begin{array}{l}\text { Naimona Nyi } \\
\text { Mountains }\end{array}$ & -7.12 & -8.44 & -0.26 & $\begin{array}{l}\text { MSS,TM, } \\
\text { ASTER }\end{array}$ & $\begin{array}{l}\text { Unsupervised } \\
\text { Classification, } \\
\text { NDSI, Manual } \\
\text { correction }\end{array}$ & 1976-2003 & Ye et al., 2007 \\
\hline $\begin{array}{l}\text { Pumqu River } \\
\text { Basin }\end{array}$ & -131.24 & -8.98 & -0.30 & $\begin{array}{l}\text { Topographic } \\
\text { map, ASTER }\end{array}$ & $\begin{array}{c}\text { Visual } \\
\text { interpretation }\end{array}$ & $\begin{array}{c}1970 s-200 \\
0\end{array}$ & Jin et al., 2004 \\
\hline $\begin{array}{l}\text { Mt. Qomo- } \\
\text { langma }\end{array}$ & -501.91 & -15.63 & -0.52 & MSS, TM & $\begin{array}{l}\text { Object-oriented } \\
\text { method }\end{array}$ & 1976-2006 & Nie et al., 2010 \\
\hline $\begin{array}{l}\text { Heihe River } \\
\text { Basin }\end{array}$ & -130.51 & -36.08 & -0.60 & TM, ETM & $\begin{array}{l}\text { Object-oriented } \\
\text { method }\end{array}$ & $\begin{array}{c}1960 s-200 \\
7 / 2011\end{array}$ & This study \\
\hline
\end{tabular}

To investigate reasons why glaciers area reduced so fast in the Heihe River Basin, the affect of regional climate change (temperature and precipitation) was the important reason, single glacier area size was also the main affecting factor (Jóhannesson et al., 1989). The area of 895 glaciers in this region was less than $1 \mathrm{~km}^{2}$, its number accounted for $92.55 \%$ in the whole area. Moreover, the smaller the glaciers were, the more sensitive of glaciers to climate change, area reducing and terminal shrinking were faster (Jóhannesson et al., 1989).

\subsubsection{Effects of climate change on glaciers change}

Water (precipitation), heat (temperature) and their combination are the main climate factors affecting glaciers development. Precipitation and temperature and their inter-annual change jointly determine glaciers nature, development and evolution (Xie et al., 2010), temperature 
decide the melting, and precipitation affect the accumulation (Li et al., 2003). In order to analyze the influence of temperature and precipitation on glaciers change in this region, six meteorological stations were chosen according to location of the study region, i.e. Tuole, Yeniugou, Qilian, Zhangye, Gaotai and Jiuquan. In Figure 8, the average temperature of the six stations showed increasing trends. The rate of temperature increasing in Tuole, Yeniugou, Zhangye and Qilian was larger than $0.30^{\circ} \mathrm{C} / 10 \mathrm{a}$ (statistically significance at the 0.001 level), and the increasing rate of Jiuquan and Gaotai was larger than $0.20^{\circ} \mathrm{C} / 10 \mathrm{a}$ (significance at the 0.001 level). The trend magnitudes were all higher than the rate of global average temperature increasing rate $\left(0.148^{\circ} \mathrm{C} / 10 \mathrm{a}\right)$ (IPCC, 2007). And the increasing warming trend of each meteorological station after 1990 was generally obvious. Similar to temperature change, the trend of annual precipitation of each meteorological station also rose slightly. The increasing rate of Tuole and Yeniugou was higher than $13.0 \mathrm{~mm} / 10 \mathrm{a}$, and the average increasing rate of Jiuquan, Zhangye, Gaotai and Qilian was higher than $2.0 \mathrm{~mm} / 10 \mathrm{a}$. According to $\operatorname{Kang}(1996)$ about relationship between glacial equilibrium line (ELA) and summer temperature from 12 glaciers in the High Asia, glacier equilibrium lines increased by a height of $100-160 \mathrm{~m}$ if
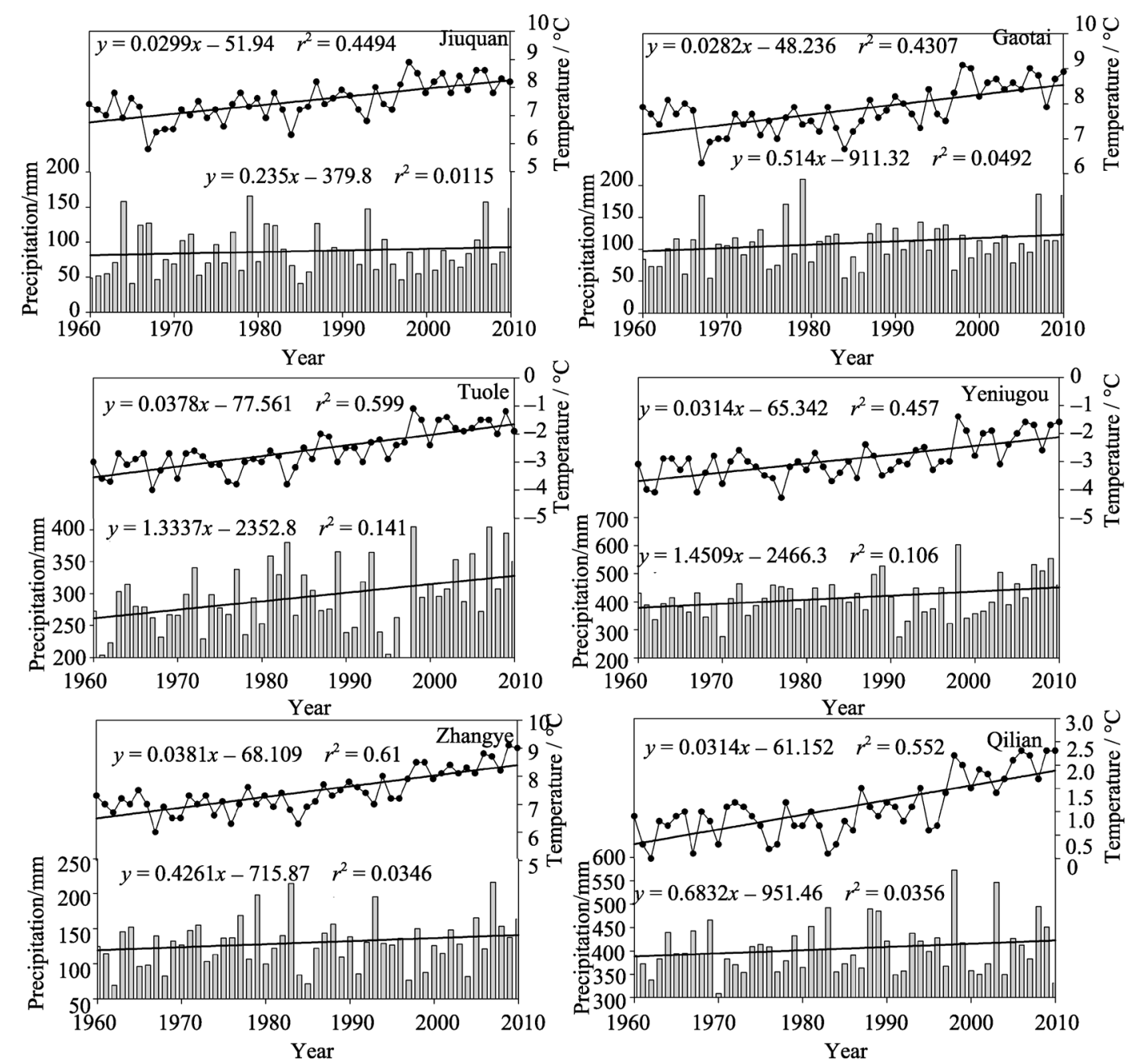

Figure 8 Annual temperature and precipitation change of the last 50 years in the Heihe River Basin 
summer temperature rose by $1{ }^{\circ} \mathrm{C}$. If keep the glacial equilibrium line unchanged, solid precipitation needed to add more than $40 \%$, or even an increase of approximately 1 times (Kang et al., 1996). Obviously, under this climate change background, although precipitation increased, the sensitivity of glaciers on temperature became stronger. With temperature rising, the supply from increased precipitation can not compensate for the loss of glaciers mass ablation, and then the glaciers in the Heihe River Basin were still shrinking.

\section{Conclusions}

This paper studied the glaciers change information using object-oriented information extraction technology in the Heihe River Basin (including Heihe River and Beida River) since the 1960 s to $2007 / 2011$. Some conclusions can be drawn as follows:

(1) The number of 967 glaciers decreased to 800 in the Heihe River Basin from the 1960s to $2007 / 2011$; glaciers area reduced from $361.69 \mathrm{~km}^{2}$ to $231.17 \mathrm{~km}^{2}$, a total of $130.51 \mathrm{~km}^{2}$ was lost, the ratio of area shrinking was $36.08 \%$, and the average of each glacier decreased by $0.14 \mathrm{~km}^{2}$.

(2) The regional differences of glacier distribution and changes in the Heihe River Basin were obvious: the rate of glacier retreat in the Heihe River is 16\% larger than Beida River; glacier terminal mainly distributed in $4300-4400 \mathrm{~m}, 4400-4500 \mathrm{~m}$ and $4500-4600 \mathrm{~m}$; the number of glacier decreased significantly at 4100-4200 $\mathrm{m}$ and $4200-4300 \mathrm{~m}$, but 4500-4800 $\mathrm{m}$ showed an increasing trend.

(3) A total of 895 glaciers were less than $1 \mathrm{~km}^{2}$ in the Heihe River Basin, accounting for $92.55 \%$ of the whole area, due to small glaciers were more sensitive to climate change, compared with other glaciers in mountains of western China, recession rate of glaciers was higher in the Heihe River Basin.

(4) Data from six meteorological stations showed that, with temperature rising, supply from increased precipitation can not compensate for the loss of glacier mass ablation, which is the key factor affecting glacier retreat in the Heihe River Basin.

\section{Acknowledgement}

The authors are very grateful to USGS (U.S. Geological Survey, http:/www.usgs.gov) for the Landsat image data and the Chinese Meteorological Science Data Sharing Service Network (http: //cdc.cma.gov.cn) for the meteorological data.

\section{References}

Baatz M, Schape A, 2000. Multiresolution segmentation: An optimization approach for high quality multi-scale image segmentation. Angewandte Geographische Information sver Arbeitung, 12: 12-23.

Benz U C, Hofmann P, Willhauck G et al., 2004. Multi-resolution, object-oriented fuzzy analysis of remote sensing data for GIS-ready information. Journal of Photogrammetry and Remote Sensing, 58(3/4): 239-258.

Blaschke T, 2010. Object based image analysis for remote sensing. Journal of Photogrammetry and Remote Sensing, 65: 2-16.

Blaschke T, Hay G J, 2001. Object-oriented image analysis and scale-space: Theory and methods for modeling and evaluating multiscale landscape structure. International Archives of Photogrammetry and Remote Sensing, 34(4): 22-29.

Bolch T, 2007. Climate change and glacier retreat in northern Tian Shan (Kazakhstan/Kyrgyzstan) using remote 
sensing data.Global and Planetary Change, 56: 1-12.

Chen Jianming, Liu Chaohai, Jin Mingxie, 1996. Application of the repeated aerial photogrammetry to monitoring glacier variation in the drainage area of the Urumqi River. Journal of Glaciology and Geocryology, 18(4): 331-336. (in Chinese)

Feng Qi, Cheng Guodong, Endo Kunihiko, 2002. Towards sustainable development of the environmentally degraded Heihe River Basin, China. Hydrological Science Journal Des Sciences Hydrologiques, 46(5): 647-658.

Guo Jiancong, Li Peijun, Xiao Xiaopai, 2008. A hierarchical segmentation method for multispectral imagery. Acta Scientiarum Naturalium Universitatis Pekinensis, 3: 123-127. (in Chinese)

Haeberli W, Cihlar J, Barry R G, 2000. Glacier monitoring within the Global Climate Observing System. Annals of Glaciology, 241-246.

Hall D K, Bayr K J, Bindschadler R et al., 2001. Changes in the Pasterze Glacier, Austria, as measured from the ground and space. The 58th Eastern Snow Conference, 197-193.

Hall D K, Bayr K, Schfner W et al., 2003. Consideration of the errors inherent in mapping historical glacier positions in Austria from ground and space (1893-2001). Remote Sensing of Environment, 86: 566-577.

Houghton J T, 2001. Climate Change 2001: The scientific basis. Contribution of Working Group I to the Third Assessment Report of the Intergovernmental Panel on Climate Change. Cambridge: Cambridge University Press.

Huai Baojuan, Li Zhongqin, Sun Meiping et al., 2013. Discussion of RS methods for glacier outline detection: A case study in Headwaters of the Kanas River. Arid Zone Research, 30(2): 372-377. (in Chinese)

IPCC, 2001. Climate Change 2001: Impacts, Adaptation, and Vulnerability. Summary for Policymakers. Report of Working Group II of The Intergovernmental Panel on Climate Chang. Cambridge: Cambridge University Press, 2007.

IPCC, 2007. The Fourth Assessment Report of the Intergovernmental Panel on the Climate Change. Cambridge: Cambridge University Press: 1-996.

Jia Wenxiong, He Yuanqing, Li Zongxing et al., 2008. The regional difference and catastrophe of climatic change in Qilian Mt. Region. Acta Geographica Sinica, 63(3): 257-269. (in Chinese)

Jin Rui, Che Tao, Li Xin et al., 2004. Glacier Variation in the Pumqu Basin Derived from Remote Sensing Data and GIS Technique. Journal of Glaciology and Geocryology, 26(3): 261-266. (in Chinese)

Jóhannesson T, Raymond C, Waddington E, 1989. Time-scale for adjustment of glaciers to changes in mass balance. Journal of Glaciology, 35: 355-369.

Kang Ersi, 1996. Energy balance characteristics and mass balance change calculation research of cryosphere in High Asia. Journal of Glaciology and Geocryology, 18(Suppl.): 12-22. (in Chinese)

Lahousse T, Chang, KT, Lin YH, 2011. Landslide mapping with multi-scale object-based image analysis: A case study in the Baichi watershed, Taiwan. Natural Hazards and Earth System Sciences, 11: 2715-2726, doi: 10.5194/nh ess-11-2715-2011.

Laliberte A S, Rango A, Havstad K M et al., 2004. Object-oriented image analysis for mapping shrub encroachment from 1937 to 2003 in southern New Mexico. Remote Sensing of Environment, 93(1/2): 198-210.

Li Zhongqin, Han Tianding, Jing Zhefan et al., 2003. A summary of 40-year observed variation facts of climate and Glacier No.1 at headwater of Urumqi River, Tianshan, China. Journal of Glaciology and Geocryology, 25(2): 117-123. (in Chinese)

Liu Shiyin, Ding Yongjian, Zhang Yong et al., 2006. Impact of glacier change on water resources in the Tarim River Basin. Acta Geographica Sinica, 61(5): 482-490. (in Chinese)

Liu Shiyin, Lu Anxin, Ding Yongjian et al., 2002a. Glacier fluctuations and the inferred climate changes in the Anyêmaqên mountains in the source area of the Yellow River. Journal of Glaciology and Geocryology, 24(6): 701-707. (in Chinese)

Liu Shiyin, Shen Yongping, Sun Wenxin et al., 2002b. Glacier variation since the maximum of the Little Ice Age in the western Qilian Mountains, Northwest China. Journal of Glaciology and Geocryology, 24(3): $227-233$. (in Chinese)

Lu Anxin, Yao Tandong, Liu Shiyin et al., 2002. Glacier change in the Geladandong area of the Tibetan Plateau monitored by remote sensing. Journal of Glaciology and Geocryology, 24(5): 559-562. (in Chinese)

Nie Yong, Zhang Yili, Liu Linshan et al., 2010. Monitoring glacier change based on remote sensing in the Mt. Qomolangma National Nature Preserve, 1976-2006. Acta Geographica Sinica, 65(1): 13-28. (in Chinese)

Ning Baoying, He Yuanqing, He Xianzhong et al., 2008. Advances on water resources research in Heihe River Basin. Journal of Desert Research, 28(6): 1180-1185. (in Chinese)

Paul F, Kaab A, Maisch M et al., 2000. The new remote sensing derived Swiss glacier inventory: Methods. Annals of Glaciology, 34: 355-361.

Qin Dahe, Xiao Cunde, Ding Yongjian et al., 2006. Progress on cryospheric studies by international and Chinese communities and perspectives. Journal of Applied Meteorological Science, 17(6): 649-656. (in Chinese)

Schiewe J, Tufte L, Ehlers M, 2001. Potential and problems of multi-scale segmentation methods in remote sens- 
ing. GeoBIT/GIS, 6: 34-39.

Serandre I, Barbero R, Rabagliati R et al., 1999. Glacier retreat in the 1980s in the Breonie, Aurine and Pustersi group (eastern Apls, Italy) in Landsat TM. Hydrological Science Journal des Sciences Hydrologiques, 44(2): 279-296.

Shangguan Donghui, Liu Shiyin, Ding Yongjian et al., 2004. Glacier changes at the head of Yulongkaxi river in the west Kunlun Mountains in the past 32 years. Acta Geographica Sinica, 59(6): 855-862. (in Chinese)

Shi Yafeng, 2001. Estimation of the water resource affected by climatic warming and glacier shrinkage before 2050 in West China. Journal of Glaciology and Geocryology, 23(4): 333-341. (in Chinese)

Shi Yafeng, Liu Shiyin, 2000. Estimation on the response of glaciers in China to the global warming in the $21 \mathrm{st}$ century. Chinese Science Bulletin, 45(7): 668-672.

Shi Yafeng, Shen Yongping, Hu Ruji, 2002. Preliminary study on signal, impact and foreground of climatic shift from warm-dry to warm-humid in Northwest China. Journal of Glaciology and Geocryology, 24(3): $219-226$. (in Chinese)

Sidjak R W, Wheate R D, 1999. Glacier mapping of the Illecillewaet ice field, British Columbia, Canada, using Landsat TM and digital elevation data. International Journal of Remote Sensing, 20(2): 273-284.

Silverio W, Jaquet J M, 2005. Glacial cover mapping (1987-1996) of the Cordillera Blanca (Peru) using satellite imagery. Remote Sensing of Environment, 95(3): 342-350.

Tang Guoan, YangXin, 2006. GIS Spatial Analysis Experimental Course. Beijing: Science Press. (in Chinese)

Wang Puyu, Li Zhongqin,Gao Wenyu et al., 2011a. Glacier changes in the Heihe River Basin over the past 50 years in the context of climate change. Resources Science, 33(3): 399-407. (in Chinese)

Wang Shengjie, Zhang Mingjun, Li Zhongqin et al., 2011b. Glacier area variation and climate change in the Chinese Tianshan Mountains since 1960. Journal of Geographical Sciences, 21(2): 263-273.

Wang Shengjie, Zhang Mingjun, Pepin N C et al., 2014. Recent changes in freezing level heights in High Asia and their impact on glacier changes. Journal of Geophysical Research: Atmospheres, 119, doi: 10.1002 /2013J D02 0490.

Wang Zongtai, 1981. Glacier list of China Qilian Mountains. Lanzhou: Institute of Glaciology and Cryopeclogy, Chinese Academy of Sciences, 58-61. (in Chinese)

Wang Zongtai, Su Hongchao, 2003. World and China's glacier distribution and water resources significance. Journal of Glaciology and Geocryology, 25(5): 500-503. (in Chinese)

Wei Yuchun, Tang Guoan, Yang Xin et al., 2007. Remote Sensing Digital Image Processing Tutorial. Beijing: Science Press. (in Chinese)

Willmes S, Bareiss J, Haas C et al., 2009. Observing snowmelt dynamics on fast ice in Kongsfjorden, Svalbard, with NOAA/AVHRR data and field measurements. Polar Research, 28(2): 203-213, doi: 10.1111/j.1751-8369. 2009.00095.x

Xiao Xiangming, Shen Zhenxi, Qin Xiaoguan, 2001. Assessing the potential of vegetation sensor data for mapping snow and ice cover: A normalized difference snow and ice index. International Journal of Remote Sensing, 22 (13): 2479-2487.

Xie Zichu, Liu Chaohai, 2010. Introduction of Glaciology. Shanghai: Shanghai Kexuepuji Press, 425. (in Chinese)

Yang Yong, Chen Rensheng, Ji Xibin, 2007. Variations of glaciers in the Yeniugou Watershed of Heihe River Basin from 1956 to 2003. Journal of Glaciology and Geocryology, 29(1): 100-106. (in Chinese)

Yang Zhenniang, 1991. Glacier Water Resources in China. Lanzhou: Gansu Science and Technology Press, 72. (in Chinese)

Yao Tandong, Liu Shiyin, Pu Jianchen et al., 2004. Glacier retreat in High Asia and their impacts to water resource of Northwest China. Science in China (Series D), 34(6): 535-543. (in Chinese)

Ye Qinghua, Chen Feng, Yao Tandong, 2007. Tupu of glacier variations in the Mt.Naimona Nyi region, Western Himalayas, in the last three decades. Journal of Remote Sensing, 11(4): 511-520. (in Chinese)

Ye Qinghua, Kang Shichang, Chen Feng et al., 2006. Monitoring glacier variation on Geladandong mountain, central Tibetan Plateau, from 1969 to 2002 using remote sensing and GIS technologies. Journal of Glaciology, 52(179): 537-545.

Yellow River Conservancy Committee, 2010. Overview of Heihe River Basin. http://www.yellowriver.gov.cn/ vh/heihe/lykk.php, 2010-06-22. (in Chinese)

Zhang Huawei, Lu Anxin, Wang Lihong et al., 2010. Glacier change in the Lenglongling Mountain monitored by remote sensing. Remote Sensing Technology and Application, 25(5): 682-686. (in Chinese)

Zhang Huawei, Lu Anxin, Wang Lihong et al., 2011a. Glacier change in the Shulenan Mountain monitored by remote sensing. Journal of Glaciology and Geocryology, 33(1): 8-13. (in Chinese)

Zhang Minhua, 2005. Extracting the temperate glacier information in the Mount Namjagbarwa, Tibet Autonomous Region, based on ETM+ image. Journal of Glaciology and Geocryology, 27(2): 226-232. (in Chinese)

Zhang Tingbin, Zhang Jianping, Wu Hua et al., 2011b. Variation of the glaciers in Nyingchi Municipality of Tibet Autonomous Region during 1990-2000. Journal of Glaciology and Geocryology, 33(1): 14-20. (in Chinese) 